\title{
The Experience of Solidarity in Poland under Communist Rule and Thereafter
}

\author{
Magdalena SOLSKA ${ }^{1}$ \\ University of Fribourg
}

\begin{abstract}
Although Solidarność was the largest mass movement in the history of after-war Europe, the experience of solidarity during that time in communist Poland has barely been analysed. Drawing on historical accounts of the events in the 1980s and press interviews with Solidarność members, this paper attempts to bridge this gap and identifies key aspects of the experienced solidarity. It argues that the solidarity under communism in Poland derived not only from the common enemy - the communist party state - but was deeply rooted in Catholic social thought and the national identity. It was driven mainly by ideas of protection of human dignity, mutual aid, participation and a demand for life in truth. Since 2015, the new social policy has had initially positive impact on income inequality, birth rates and poverty but must be accompanied by further measures to obtain a long-term character.
\end{abstract}

Keywords: Solidarność, solidarity, Poland, communist system, inequalities

\section{Introduction}

In the eyes of Timothy Garton Ash (1999: 351), Solidarność was "the most infectiously hopeful movement in the history of contemporary Europe". Its story commenced in August 1980 with the occupation strike ${ }^{2}$ at the Lenin Shipyard in Gdańsk. Followed by a rapid formation of solidarity committees in other factories across the whole country, the emergent movement that only later came to be known as Solidarnośs $c^{3}$ was characterized by a peaceful character, very good organization, and the truly unprecedented cooperation between workers, intellectuals, farmers

\footnotetext{
${ }^{1}$ Dr. Magdalena Solska is a senior researcher at the Department of Social Work, Social Policy and Global Development at the University of Fribourg (magdalena.solska@unifr.ch).

${ }^{2}$ The occupation strike was a conscious choice of the workers. 10 years before, the communist party suppressed the protests in Gdańsk with force, causing dozens of victims.

${ }^{3}$ The very name Independent Self-Governing Trade Union Solidarność was agreed upon in September 1980, once Wałęsa invited the delegates from the regional branches to discuss the organization and program of the newly established trade union. The choice of the name Solidarność (engl. solidarity) was accidental and was apparently proposed by Karol Modzelewski, a prominent member of Solidarność in Silesia.
} 
and the Catholic Church. The spontaneous and massive support for the striking workers urged the Communist Party to accept their 21 demands. ${ }^{4}$ The Gdańsk Agreement between the central strike committee headed by Lech Wałęsa and the Deputy Prime Minister Mieczysław Jagielski was signed on August 31, 1980 while the event was broadcast on state television. As a result, the first trade union under communist rule was legalized.

This essay does not intend to provide a comprehensive account of the Solidarność movement. It has already been analysed from different perspectives: historical, sociological, culturalanthropological, philosophical (see Touraine et al. 1983; Staniszkis 1984; Ost 1990; Kubik 1994; Garton Ash 1999). Surprisingly enough though, the research interested in concepts such as solidarity or community has largely overlooked the experience of solidarity in Poland in 1980-81 (Beyer 2007: 207; Stawrowski 2000). What is more, the experience of solidarity under totalitarian communism must have differed from the notions of solidarity known in Western democracies. Therefore, this essay aims to detect the main values and principles that guided Solidarność and its members. What was the idea of solidarity about, and how was it expressed under communist rule?

Theoretical perspectives on solidarity can be divided into three distinct types (Hechter 2001: 14588-14591). The structuralist perspective argues that solidarity arises from common material interests; rational individuals create solidary communities and discover common interests especially when faced with common antagonists. When the mutual interactions occur regularly, they may engender affective feelings that encourage the compliance with collective obligations. From the rational choice perspective, solidarity arises from mutual interdependence and control capacity among the group members. Rational individuals form solidary groups to obtain access to goods which are not easily available elsewhere. Finally, the normative perspective suggests that solidarity arises from common values and norms. Because the Polish people could not pursue their material interests under communism but rapidly and spontaneously joined Solidarność, the shared values and norms giving rise to solidarity, I argue, must have stemmed from the preserved national tradition and identity as well as from Catholic social thought.

Catholic tradition sees solidarity not only as a norm guiding individuals but also as a principle for institutions and social relations, determining various aspects of economic, political, and social life. In this vein, Gerald Beyer presents three moments or sequential steps of solidarity (2009: 134-135): 1) recognition of factual solidarity, i.e., human interdependence as an anthropological fact; 2) solidarity as an ethical imperative; 3 ) solidarity as a principle enshrined in policies and institutions. Whereas the first step pertains to an attitude of empathy among community members, the second step is related to an initial and immediate response or aid. Indeed, both aspects of solidarity were noticeable during the Solidarnośc time. Finally, the institutionalization of solidarity and sustainable support of those marginalized in order to empower them to advance personal and social change can only be pursued in the context of political and economic freedom.

\footnotetext{
${ }^{4}$ The demands included above all the release of political prisoners, the passing of a censorship law, the disclosure of information about the Polish People's Republic's external debt and, most importantly, the legalization of a free trade union. The communists agreed also that future appointments in factories would be made on the basis of qualification and not due to party membership. See more in Machcewicz 2020: 5.
} 
This paper tries therefore to identify and describe key components of experienced solidarity, drawing on historical accounts of the events in the 1980s, press interviews with Solidarność members and several studies on the subject. Against the backdrop of the national features of the communist system in Poland, as depicted in the first section on "National characteristics of the communist system in Poland", the paper discusses solidarity as acting in unity despite ideological and social differences. Further, the paper regards solidarity as an "ethical community" (Stawrowski 2002) $)^{5}$ and identifies key elements of solidarity experienced during the Solidarność time: the idea of protection of human dignity, mutual aid, participation and a demand for life in truth. In the final section, the experience of solidarity in post-communist Poland will be discussed.

\section{National Characteristics of the Communist System in Poland}

The communism in Poland shared typical features of a totalitarian system, ${ }^{6}$ such as the leading role of the Communist Party (Polish United Workers' Party, PZPR), the state party's control over economic, cultural and social subsystems, arbitrary state repression and coercion (especially until the 1970s), and the omnipresent ideology. In sum, political, social and media pluralism $^{7}$ was officially prohibited. Moreover, Poland's communism exhibited some specific, national characteristics, ${ }^{8}$ unfamiliar to other communist countries in Central and Eastern Europe, which demonstrated the national way towards the ideal of a communist society. Maćków (2014: 32-33) mentions three forms of non-communist organizations in Poland: legal and heteronomous, such as the satellite party United People's Alliance (ZSL, a quasi-party completely dependent on PZPR); illegal but autonomous, such as circles of dissidents (e.g., the Workers' Defence Committee, KOR ${ }^{9}$; the Confederation of Independent Poland, KPN); and legal and autonomous, usually linked to the Catholic Church (e.g., Znak, engl. sign). The latter - so atypical for a communist system - were not allowed to openly question the system, but neither did they have to permanently reaffirm the Communist Party's claim to power and the communist ideology. None of these actors could compete with the Communist Party for influence, not to mention for power. ${ }^{10}$ Maryjane Osa (2003: 154-168) notes that the mainstream Catholic organizations were reestablished as a result of anti-Stalinist protests in 1956-57 and became permanent

\footnotetext{
${ }^{5}$ For Stawrowski (2002: 114), the "ethical community" of Solidarność members was based, first of all, on religious bonds and resorted to the language of ethics.

${ }^{6}$ For the discussion of different concepts of totalitarianism, see Maćków 2005: 23-41.

${ }^{7}$ Pluralism is understood as the existence of autonomous organizations that act to organize and represent interests and compete with each other and with the state.

${ }^{8}$ To be sure, other countries also displayed national peculiarities; e.g., in Czechoslovakia, the office of the president remained in place throughout the whole communist period.

${ }^{9} \mathrm{KOR}$ was founded by several intellectuals in response to the government repression of workers participating in the 1976 demonstrations. It organized legal and financial support for detainees and their families. It sought the prisoners' release through open letters to the government and writing articles in the western press, unveiling events in Poland. It also contributed to the development of an underground press with periodicals such as Robotnik (Osa 2003: 134-135).

${ }^{10}$ All these features point to the totalitarian character of the communist system in Poland. Conversely, in authoritarian systems, political pluralism, i.e., opposition and political parties, are legal but usually constrained in their activities, especially when they try to seriously challenge the incumbents (see Linz 2000). The oppositional actors can compete for influence and criticize the incumbents but it is usually hardly possible for them to realistically compete for power. However, due to a certain
} 
fixtures of what she called "opposition domain". In 1978-79, the existing networks of organizations represented different social and ideological leanings, such as civic, liberal, mainstream Catholic, nationalist and radical youth. ${ }^{11}$

From the perspective of the regime, the existence of such non-communist actors constituted a valve for society's dissatisfaction. They partially legitimized the communist system, especially towards the Western world, and their very presence expressed the extremely limited but existing potential of a systemic evolution. The number of such organizations pointed to the general rejection of the imposed communist system by the Polish nation and meant a latent but lasting legitimacy crisis of that system.

Undoubtedly, the occupation strike in Gdańsk and the unfolding massive social movement unveiled the functional and legitimacy crisis of Polish communism. In fact, the erosion of the central planning system and the subsequent deep economic crisis lasted until the end of communism in 1989 (Kubik 1994: 240). What is more, the widespread corruption led to an overall perception of a growing social gap:

Of all the unsavory and unpopular features of the Communist system in Poland, perhaps none aroused more hostility and outrage, or contributed more to the outburst of discontent in the summer of 1980, than the existence of widespread social inequities. (Quoted in Kubik 1994: 240).

There was a growing gap between the "state society", i.e., the narrow circle of people belonging to the communist party and enjoying access to privileges of power, and the "normal society" (Maćków 1992), ${ }^{12}$ i.e., people who remained outside the communist party. The latter were particularly affected by the economic crisis, which clearly contradicted the system's egalitarian doctrine.

In the end, the very essence of communism - the merging of its economic, social and political systems as well as its lack of any alternative for political participation or expression of interests other than through the ideological party-state - necessitated the turn to the "politics of values" (Bielasiak 2010: 43). In fact, many citizens perceived the participation in the formal communist institutions as a ritual rather than a possibility to express their own preferences (Marody 1990: 263-264). On the whole, the observed etatization of the public sphere and the purposeful destruction of social self-organization especially before 1976 led to a phenomenon called "sociological vacuum" (Nowak 1979), characteristic for a society of alienated individuals, bereft of any sphere of independent institutional intermediation between state and nation

degree of societal plurality and a lower level of state coercion, especially since 1976, Linz and Stepan (1996: 255) regard the political system in Poland from the 1970s till 1989 as "post-totalitarian", but not yet authoritarian.

${ }^{11}$ Liberal meant commitment to systemic reforms, civil liberties and neutrality towards the economic system and towards the alliance with the Soviet Union. Nationalist implied a strong anti-communist attitude, a rejection of the alliance with the USSR and support for historical traditions and national culture. Civic organizations attracted the secular left and progressive Catholics focused on human rights and promoted ideological diversity and civic culture; they advocated economic reforms and tolerated the alliance with the USSR (see Osa 2003:156).

${ }^{12}$ As Maćków (1992) argues, it is exactly the condition of normal society that shows whether a society managed to preserve its tradition, national identity and national awareness during communism. The frequent strikes in Poland pointed to the maintenance and preservation of national identity and culture, which resulted in a national resistance against the imposed totalitarian ideology and state. 
(Lubecki and Szczegóła 2007: 22). Instead, individual preferences were based on pro- or antiregime stances - the "us" versus "them" dichotomy - rather than on social or economic interests (Bielasiak 2010: 43-45). However, that does not mean that social bonds and solidarity behind the mass movement Solidarność were rooted solely in the opposition towards the common enemy.

\section{Solidarity Under Communism: Acting in Unity Despite Differences}

Solidarność brought together a massive amount of people with wide-ranging political and economic attitudes. It had close to ten million members, out of approximately twelve and a half million employees potentially qualified (Garton Ash 1999: 163). One of the most remarkable features of that time was, therefore, the ability of Poles to rise above hierarchies, social divides and differences in political as well as economic views (Gawin 2002: 173-174, Beyer 2007: 209). For instance, as regards economy, the diversity of convictions within Solidarność ranged from economic liberalism to a socialism based on more social privileges, egalitarianism and the idea of self-government (Dudek 2002: 148-149). Most accounts of the events in the 1980s describe an experience of togetherness, oneness and community and identify these as central goals of the Solidarność movement (Beyer 2007: 209). This does not negate the instances of hostility within the movement. Władysław Frasyniuk (2020:11) notes, for instance, that some members of Solidarność exhibited nationalist, even antisemitic views. But the idea and necessity of tolerance prevailed at that time.

From the very beginning, the solidarity between workers was a crucial element of the strike. Wałęsa rejected a deal that would have implemented differential pay raises to the Lenin shipyard in Gdańsk differential pay raises. Encouraged by his colleagues, he demanded the same pay raise for all workers. In the end, the workers agreed on a compromise deal, but Wałęsa called on the members of Solidarność to engage in a larger solidarity strike with workers from other economic sectors who had not won any concessions. This resulted in the formation of the Interfactory Strike Committee (Garton Ash 1999: 44-46; Mazur 2018).

However, most noteworthy is the fact that it was the Workers' Defence Committee (KOR), established by intellectuals in 1976 to help persecuted workers, that preceded the formation of the trade union movement Solidarność. In this way, the gap between workers and intellectuals, particularly apparent in 1970, was finally bridged (Garton Ash 1999: 20). Despite the recurrent debate as to whether Solidarność was a trade union, a revolutionary social movement or a peaceful national uprising (Dudek 2002: 143), it is undeniable that workers and intellectuals cooperated to pursue their common goals. The unprecedented accord between farmers, factory workers, and intellectuals epitomized the nature of solidarity in those days. As recollected by Henryk Wujec (2020), workers sometimes traveled long distances to strike with farmers or to support striking nurses and interned dissidents. Intellectuals appealed to Polish history and culture to bring Solidarność members from various social strata together (see Garton Ash 1999: 117-40, 317). In this vein, in a sermon during a rural solidarity strike in Rzeszów in 1981, Bishop Tokarczuk of Przemyśl described that unity as "a school of Christian life" and "one great family" 
(Garton Ash 1999: 135). Interestingly enough, even the majority of the communist party members belonged to Solidarność in 1981. They even participated in the largest strike in the history of the Soviet bloc in March of that year (Garton Ash 1999: 165).

The massive and spontaneous character of the Solidarność movement could not emerge solely due to the existence of a common enemy. As Stawrowski (2002: 104) mentions, "the most relevant meaning of the first Solidarność was the common awareness of the deep bond with other people". Given the context of an atomized society exposed to communist ideology and propaganda for several decades, the connection between people must have had deep national and religious roots that survived the constant intervention of a total party-state. This is why Stawrowski (2002: 114) refers to an "ethical community" and "ethical bonds" expressed in the language of ethics, propagated by the church and used by the dissident circles. Those bonds were rooted in common values such as freedom, truth, dignity and justice. ${ }^{13}$

\section{Key Aspects of Solidarity in 1980-1981}

\section{Solidarity as a quest for the dignity of the human person}

At the core of that "ethical bond" was a specific anthropology - a vision of the human person based on dignity. In this sense, solidarity was based on the Christian conception of the human person. "This Christian anthropology, even if as a forgotten or latent heritage, was the real basis of solidarity and Solidarność" (Gowin 2002: 29). According to journalist and writer Ryszard Kapuściński, it was not the social demands but exactly that quest for the dignity of the human person that constituted the primary motivation for the events unfolding in 1980-81. Respecting that dignity necessitated "new interpersonal relations everywhere and on every level, a principle of mutual respect for all without exception, a principle according to which one's subordinate is also one's partner"(quoted in Gawin 2002: 168). In this vein, Gawin (2002: 169) mentions professors and shipyard workers sitting next to one another on the ground in protest, and reflecting on each other's arguments (see also Frasyniuk 2020 ). ${ }^{14}$

The essential part of the ethical bonds was the readiness for dialog and compromise. A chaplain of Solidarność, priest and philosopher Józef Tischner, wrote in his Ethics of solidarity that solidarity must entail true dialogue, which always acknowledges that "the other, from his point of view, is always to some extent right" (Tischner 2005: 42). Indeed, despite disagreements, Solidarność was able to seek compromises within the movement itself. It was also ready to pursue a dialogue with the communists, even after the imposition of martial law in 1981 and the delegalization of Solidarność (Garton Ash 1999: 266). This eventually led to the Round Table Agreement in $1989^{15}$ and to the fall of communism in the whole region. At the same time, the readiness for dialogue did not exclude strikes and overt opposition. Drawing on the work of Karol

\footnotetext{
${ }^{13}$ For Stawrowski (2002), the ethical bonds were apolitical, i.e., the exclusive claim to power of the Communist Party remained uncontested.

${ }^{14}$ Beyer (2007: 219) notes that even if some individuals acted in a discriminatory manner at times, the statutes and ethos of Solidarność reveal that its members generally all sought the same thing: respect for human dignity.

${ }^{15}$ The Round Table Agreement included first and foremost semi-free elections to the Sejm (Lower Chamber of Parliament, 460 seats) and free elections to the newly established Senate (Upper Chamber of Parliament, 100 seats). That meant that only
} 
Wojtyła and the Roman Catholic Church's role within Solidarność, Beyer noted that opposition and political dissent could be a manifestation of solidarity, especially when such dissent was a form of participation in the common good to achieve all that "which was true and just" (Beyer 2007: 210-11). In this context, what was seen as true and just was the social order that would fulfil the spiritual and material needs of the human person.

\section{Solidarity as mutual aid}

Under communism, the notion of common good was neither understood nor respected. In the early eighties, however, the aid directed towards the victims of state oppression became noticeable. This was linked to that new sense of trust in the human person (see Krzemiński 2010) the rediscovered ethical bond. Although "solidarity is directed toward everyone and not against anyone", Tischner (2005: 38) also contends that solidarity was primarily directed toward those who had been wounded by others and whose suffering was avoidable. Tischner's argument is based on the parable of the Good Samaritan: the pain of the person lying in the road is not the result "of an illness, unlucky coincidence, advanced age, but a pain inflicted by another man. It was a man who prepared this fate for another man [...] [T] his is exactly what moves the conscience and calls for solidarity" (Tischner 2005: 40-41). While solidarity should also include those who suffer from other causes, solidarity with those who suffer from other persons is particularly "vital, strong and spontaneous" (Bonowicz 2002: 69). However, solidarity is not considered to be the same as compassion, as solidarity implies mutuality and appeals to the activity and the subjectivity of the oppressed. It encourages to carry each other's burden. Solidarity and aid aim at the empowerment of the oppressed and thereby at enabling them to act in solidarity with other suffering people (see Gowin 2002: 28-29).

Solidarność members often helped people persecuted by the communist regime. The best example is the strike in Gdańsk that demanded the reinstatement of Anna Walentynowicz, a shipyard worker who had been unjustly fired (Garton Ash 1999: 42-43). As Henryk Wujec (2020) notes, the idea of solidarity as aid for those suffering under the communist regime was already present before the appearance of the trade union Solidarność and expressed the general "spiritual mood" within Polish society - the mutual empathy implied by the first "step of solidarity" (Beyer 2009: 135-136). It also manifested itself in the form of KOR. Since 1977, in many Polish cities there were Students' Solidarity Committees supporting imprisoned dissidents. As mentioned above, once the strikes in Gdańsk at the Lenin Shipyard began, workers in other factories in the whole country founded solidarity committees and supported the strikes in Gdańsk by sending their representatives to the Shipyard. The underground press started to publish the Strikers' Newsletter Solidarność (pol. Strajkowy Biuletyn Informacyjny Solidarność) to inform workers in the whole country.

$65 \%$ of the seats of the Sejm (299 mandates) were reserved for the PZPR and its satellite formations; $35 \%$ of the seats (161 mandates) were freely elected (see Maćków 1989). 


\section{Solidarity as participation}

The belief in the dignity of the human person gave rise to a sense of trust and self-sacrifice for others and for the common good. The belief in the dignity of work, in turn, strengthened the desire for participation and the right to shape and influence the own life and the life of society (Stawrowski 2002: 105). According to Solidarność members, the communist regime had usurped this right (Beyer 2007: 215).

A remarkable increase in the level of social and political debate took place during the earliest years of Solidarność. Garton Ash reports that the first national congress of Solidarność was highly democratic, sometimes at the cost of efficiency of its proceedings (Garton Ash 1999: 22930; see also Gawin 2002: 173). Prior to the introduction of martial law in December 1981, the majority of Solidarność members took part in meetings of their local branches (Gawin 2002: 181).

The demand for more participation referred to social, political and economic policies (Garton Ash 1999: 304). Poles demanded the ability to maintain free trade unions and to create a system of worker management (pol. samorządy pracownicze) (see Mazur 2018) in addition to the right to political participation and freedom of assembly (Beyer 2007: 215). They maintained that unless workers at the bottom level were invested with decision-making power within a given industry, no effective strategies of just distribution of profits could be designed (Dudek 2002: 149-50; Beyer 2007: 215). As mentioned earlier, the members of Solidarność wanted work to be a form of dialogue where mutuality and respect exists between employees and employers. Without such a dialogue, work would be tantamount to exploitation. When work becomes exploitation, it becomes "senseless" (Tischner 2005: 51, Krysiak 2020: 5). The program adopted at the first national congress in September 1981 shows the main concerns of Solidarność were related to economic rights such as just wages or adequate health care. The economic vision of that program was highly egalitarian, demanding, for example, more compensation for the worse-off and combating social inequalities between different industries and regions (Dudek 2002: 149).

\section{Solidarity as a demand for a life in truth}

The idea of a life in truth permeated all dimensions of solidarity (Beyer 2007: 222). It was inherently linked to the respect for human dignity, the common good, the possibility for dialogue and freedom. Zbigniew Stawrowski (2002: 115) calls the time of Solidarność a time of mass conversion. He does not mean a return to faith in God but a decision to live according to conscience, as opposed to the dictates of communism. Tischner (2005: 38), too, contends that the deepest solidarity is exactly the "solidarity of consciences". Striving for a life without the lies of the communist ideology required that shared understanding of the human person as one imbued with dignity, capable to live in freedom and eager to participate in social life. This shared anthropology united people of different religions and ideological beliefs within Solidarność (Gowin 2002: 28).

The need for freedom in order to be able to lead a life in truth appeared frequently in statements, speeches, and conversations among Solidarność members (Garton Ash 1999: 293). That had to do with the fact that the awareness of national history and culture and the role of the Catholic Church were not erased during communism. Because the communist system aimed at 
the destruction of the uncomfortable past of its societies, the quest for a life in truth spoke volumes about the condition of national identity in a respective society. For instance, the awareness and knowledge about the NKVD murders on Polish citizens in Katyn was present within Polish society during communism (Maćków 1999: 1370). However, it was vehemently suppressed by the communist regime (Garton Ash 1999: 44). In this sense, the Solidarność movement was seen not only as a "workers' revolution", but also as a nonviolent "national-independence movement" (Dudek 2002: 150-156).

This movement achieved an alternative cultural hegemony, re-emphasizing, for instance, the celebration of 3 May Constitution Day as a symbol for Polish nationhood over the official 1 May celebrations. Similarly, the public mass gatherings during the papal visit to Poland in June 1979 symbolically delineated the public sphere as isolated from the official state (Kubik 1994: 138-146; Bielasiak 2010: 44; Marody 2011: 488). Hence, "the challenge to real existing socialism was expressed as a collective, solidarity ethos of the nation against the power of communism" (Bielasiak 2010: 43).

\section{Solidarity after Communism}

Karol Modzelewski once stated that "Solidarność was not a possession of any political party, but a national good" (quoted in Krysiak 2020: 6). However, thirty years later, strong polarization, low institutional and interpersonal trust, an irresponsible ${ }^{16}$ political class and weak political parties characterize the socio-political life in Poland. What is more, the bulk of literature on political systems considers Poland to be a paradigmatic case of democratic backsliding since 2015 when a party named Law and Justice (pol. Prawo i Sprawiedliwość, PiS), claiming to represent the values of the Solidarność movement, won the parliamentary elections. While the party rightly identified the necessity to tackle the demographic problems and to promote solidarity with the so-called losers of system transformation in contemporary Poland, PiS has also contributed to the weakening of key state institutions in the country, such as the Constitutional Tribunal (see Bill and Stanley 2020). However, some universalistic ideas of Solidarność - protection of human dignity, sense of work, search for dialogue, principle of subsidiarity and selfgovernment - could potentially constitute the basic consensus within Polish society. ${ }^{17}$ For Sartori (1987), it is exactly such a consensus at the community level that facilitates the consolidation of democracy.

Nonetheless, as Mary Ann Glendon notes, "principles such as freedom and solidarity do sit uneasily together" (quoted in Beyer 2009: 133). For many, solidarity appears in contrast to individual choice, which is crucial to human freedom (Beyer 2009: 146). In Central and Eastern Europe, regaining freedom after the imposed totalitarian system coincided with the transformation from a command economy to a market economy and with further simultaneous and

\footnotetext{
${ }^{16}$ By "irresponsibility of the political class" I understand the propensity of politicians from both ruling and opposition parties to follow personal ambitions and interests at the cost of the common good and the interests of the country.

${ }^{17}$ It is noteworthy that some of the values, such as the "respect for freedom and justice, cooperation between the public powers, social dialogue as well as on the principle of subsidiarity in the strengthening the powers of citizens and their communities" are enshrined in the Preamble to the Polish Constitution of 1997; see https://www.sejm.gov.pl/prawo/konst/angielski/kon1.htm.
} 
unprecedented reforms of all subsystems (Offe 1991: 868-72). To accomplish this reform agenda, any opposition to the painful socioeconomic change had to be weakened by demobilizing exactly those social groups that had been fighting for a free Poland within the Solidarność movement, such as workers. "There was little room for the defense of workers' interests for fear of derailing economic globalization and market competition" (Bielasiak 2010: 46). Instead, the new order

brought new values with it. The basis of the functioning of free market is the principle of free competition. In the process of competition egoism functions as a main virtue. Those who can eliminate their competitors can best fulfil their own interests. Notions such as competition, egoism, interests, which are fundamental to the new order, clearly stand in opposition to the notion of solidarity (Gawin 2002: 186; see also Taylor 2000).

Generally, the ethos of Solidarność and the idea of solidarity faded away quickly in post-communist Poland, mostly due to two reasons. First, the feud between former prominent Solidarność members from 1990 onwards, carried out between Lech Wałęsa on the one side and his former advisors from intellectual circles, Tadeusz Mazowiecki, Bronisław Geremek, Jacek Kuroń, and Adam Michnik on the other (see Beyer 2006). The most controversial subjects were the right speed of economic and political reforms and the role of former communists in the democratic Poland (see Solska 2009). Second, the unconditional popularity of neoliberalism: Polish neoliberals focused primarily on economic growth; solidarity was not a priority, especially in the first stage of the post-communist system transformation (Beyer 2006). Janusz Lewandowski, former Minister of Privatization under two governments in the early 1990s, stated unequivocally: "I choose freedom from the catalogue of values, not equality [...] Freedom understood as freedom from coercion and limitations" (quoted in Beyer 2009: 143). This dominant negative freedom was understood as freedom from and conflicted with the ideas of the Solidarność movement (Beyer 2006). Negative freedom requires the "removal of the obstacles that rise up on the way to realization of the innate rights of the individual, not to decide what the individual should do to be good wise and happy" (Szacki 1996: 196) - in other words, a person is free when no other person or institution interferes. Whereas for Solidarność freedom could be realized by means of participation in the construction of a just society and acting in solidarity meant promoting freedom and participation of others, for adherents of neoliberalism, freedom amounted to freedom from constraints and competition, especially in the economic sphere (Szacki 1996: 196-197; Beyer 2009).

Beyer (2006) also notes that the notion of freedom from contributed to a widespread indifference towards the poor in Poland after 1989. Vulnerable groups, such as farmers and children in low-income, large households, suffered the most as they were offered no aid during the system transformation and the social dialogue diminished because people were more concerned with their individual chances and progress. At the same time, the role of the Catholic Church has become ambivalent in post-communist Poland. Its interfering in politics and lack of transparency have led to a proceeding secularization. Moreover, the debate about the nature of national community and patriotism has been neglected and made the survival of ethical bonds hardly possible. 


\section{Institutionalizing Solidarity?}

Although Poland's profound transformation from a command economy to a market economy occurred in less than one generation and although the accompanying economic growth was the fastest in Europe (Bukowski and Novokment 2019), there was also a growing support for redistributive policies. This was linked to evidence that in Poland the people with the highest income profited the most from the system transformation: "The annual rate of income growth for the top $5 \%$ of the population exceeded $3.5 \%$, while the median income grew on average by about 2.5\% per year" (Brzeziński, Myck and Najsztub 2020:1). ${ }^{18}$ This research on income inequality, which was uniquely based on a combination of household survey and tax return data, shows that the Gini coefficient in 1994-2015 in Poland grew by 14-26\% (Brzeziński, Myck and Najsztub 2020). Apart from that, since 2000 the demographic problems in Poland became urgent, further exacerbated by mass migration of especially younger people to the west since 2004. ${ }^{19}$

Against the background of those structural problems, the national-conservative party Law and Justice came to power in 2015. It promised to introduce extensive social policies including the child subsidy program Family 500 plus $^{20}$, a new law reversing the previous government's unpopular pension reforms that had increased the retirement age to 67 (from 60 for women and 65 for men), and cost-free medication for seniors. Indeed, the initial results were encouraging. In July 2017, the number of births had grown by $11.5 \%$ in comparison with 2016 (Inglot 2020: 998). Out-migration flows were stabilized and even slightly reversed, with some migrants returning home (Inglot 2020: 988). It is noteworthy that Poland has also started to become an immigration country, with hundreds of thousands of Ukrainians and Belarusians moving to the country to find better jobs and more comfortable and peaceful living conditions (see Kaczmarczyk et al. 2020: 930-931).

Due to the quickly implemented Family 500 plus program, by 2016 around 3.2 million families had received a "fresh injection of cash" (Inglot 2020: 997). Hence, many ordinary Poles who previously felt second-class citizens started to sense that the government finally cared about the less well-off, helping them to regain a sense of dignity and moral worth (Szczerbiak 2019). In other words, PiS has enacted a symbolic redistribution of dignity or social prestige, empowering, in economic and cultural terms, those sections of the electorate that have often

\footnotetext{
${ }^{18}$ Similar evidence was presented by Bukowski and Novokment (2019), who drew on combined tax, survey and national accounts data. Accordingly, there was a considerable rise in inequality after communism, driven by a decisive increase in the income shares of the top groups. The authors prove that in the period 1989-2015, the top 1 percent had a total income growth almost twice as high as the bottom 50 percent (24\% versus 13\%). The highest increases took place at the start of the transformation in the early 1990s and after Poland joined the EU in 2004.

${ }^{19}$ In 2013, the EU data reported the Polish fertility rate at 1.29, whereas the EU-28 average was at 1.55. Moreover, between 1994 and 2004, the median age of the population in Poland increased from 33.4 to 39.2 years. As regards the out-migration, the number of people temporarily residing abroad doubled during the time period 2004-2005 and reached 2.5 million in 2016 (Inglot 2020: 985; see also Kaczmarczyk et al. 2020).

${ }^{20}$ It was called a child-rearing benefit (pol. świadczenie wychowawcze) and granted every family 500 złoty (ca. 120 euro) for every second and further child. Families with one child and single mothers with a child qualified for this payment only if their income fell below 800 złoty (200 euro) per person within the household. The conventional family allowance (pol. zasitek rodzinny) and the maternity allowance for mothers taking time off to raise children for up to four years (pol. zasilek wychow$a w c z y$ ), both based on social insurance and income-related, were maintained (Inglot 2020: 997).
} 
felt disregarded by mainstream Polish politics since 1989 (Smolar 2019). Even the prevalent criticism concerning the judicial reform or the abuse of public office, the occurrence of nepotism and the party patronage have not damaged the governing party's reputation (Sadura and Sierakowski 2019). The party's social policy was considered a credible attempt to redistribute the fruits of the economic transformation in a more just way.

As Inglot (2020: 998) notes, from a welfare perspective, Poland had never experienced such an increase in family support in such a short period of time. By July 2016, 2.7 million children were receiving the benefit every month. This number represented approximately $47 \%$ of all children in Poland. As a result, according to various estimations, the relative poverty in the country decreased by $20 \%$ in $2016^{21}$, among children even by $50-70 \%$ (Chrabota 2016; EAPN Polska 2020). Needless to say, large families with more than three children and those with lower income seem to have benefited the most from this social policy. At the same time, these are not necessarily the same persons who tend to migrate or the ones who postpone or dismiss having children (Inglot 2020: 998). Moreover, the birth rate increased from 1.29 in 2015 to 1.46 in 2018. However, there has been a slightly decreasing trend since 2017 (World Bank 2018).

In terms of income inequality, the impact of this social policy seems to have been only shortterm. The Gini coefficient had decreased substantially from 30.6 in 2015 to 27.8 in 2018 but increased to 28.5 in 2019 (Eurostat 2021). Many observers argue that the plain transfers of money (without considering inflation) reduce inequality only in the first years and that their effects are not visible after that (Wójcik 2019). Notwithstanding, in the run-up to parliamentary elections in 2019, the parliament overwhelmingly supported an extension of the Family 500 plus program to include first children as well (see Prawo i Sprawiedliwość 2019). The new law now covers 6.8 million children and costs ca. 43 billion zloty (ca. 10 billion euro), compared to the 23 billion annually allocated so far (Adamski 2019; Inglot 2020: 997-998). Given the almost unanimous acceptance of further social spending among Polish parliamentarians, we can agree with the argument that whereas economic neoliberalism was the politics of normality until 2015, PiS has managed to establish social spending as a new norm in Polish politics thereafter (Bill and Stanley 2020). ${ }^{22}$

However, many observers expect that the 2019 extension of the Family 500 plus program to the first child is not going to have any relevant effect as it will primarily favor affluent families (Wójcik 2019). Indeed, the poorest families have already been receiving the payment for their first child. Moreover, inequalities will not be combated by an increase of the minimum wage, which is already one of the highest in the region (Eurostat 2019). At the same time, as Brzeziński (2017) points out, the Polish tax system reduces inequalities only to a limited extent:

Direct taxes on personal income are characterised by low progressivity, and their role in reducing inequality is insignificant [...] Indirect taxes - VAT and excise duties -

\footnotetext{
${ }^{21}$ Before 2016, the average poverty rate in Poland amounted to 7.4\% (see Inglot 2020: 998).

${ }^{22}$ The 500 plus program has been criticized for lack of clearly formulated, measurable goals. Whereas a possible and wished impact on decreasing poverty, stimulating birth rates, or even diminishing emigration has been often stated by the government, it is still unclear what the indicators of its success or failure would be, and how this program (and whether in the current form) could be financed in the long run. Many criticize the negligence and underfunding of public services, such as healthcare. The symbolic role of the program - stressing the role of family and young people - and the fact that the child subsidy is not incomerelated are generally acknowledged (see Trudnowski 2017).
} 
are regressive (the poor pay proportionately more than wealthier individuals) and contribute to increasing income inequality to a greater extent than in many developing countries (Brzeziński 2017: 9).

Whereas the future of the Family 500 plus program has become indisputable, the feasibility of social policy in Poland needs to be supported by further concrete measures as well as by the mainstreaming of public services in the long run.

Solidarność fought not only for solidarity between different social groups but also for strong, independent institutions and a culture of deliberation and dialogue. The PiS politics focuses on solidarity with the worse-off and families, whereas its constant emphasis on cultural conservatism and its proximity to the Catholic Church appeals primarily to its core electorate. At the same time, the PiS-led government has unilaterally introduced controversial policy changes concerning the judicial system, public media, and public administration and thereby weakened these institutions (see Bill and Stanley 2020). This has been accompanied by a polarizing discourse, exacerbated also by the opposition parties. The idea of solidarity within Solidarność as it had evolved, consisted in mutual trust and fostering participation by creating the common good. A lasting social and institutional change can only occur on the basis of consensus. In the polarized Polish society, the idea of a common good has become elusive while parties' or personal interests often appear dominant. That is where solidarity is particularly needed today.

\section{Acknowledgements}

The author is grateful to the anonymous reviewers and the editors of socialpolicy.ch for helpful comments and feedback.

\section{Declaration of conflicting interests}

The author declared no potential conflicts of interest with respect to the research, authorship, and/or publication of this article.

\section{Funding}

The author did not receive any financial support for the research, authorship, and/or publication of this article.

\section{References}

Adamski, Mateusz (2019). W nocy Sejm rozszerzył program 500+ [At night, the Sejm broadened the 500+ program]. Rzeczpospolita, 26.04.2019. Last accessed 11.04.2021 on https://www.rp.pl/Pracaemerytury-renty/304269972-W-nocy-Sejm-rozszerzyl-program-500.html.

Beyer, Gerald J. (2007). A Theoretical Appreciation of the Ethic of Solidarity in Poland Twenty-five Years After. Journal of Religious Ethics 35(2), 207-232. 
Beyer, Gerald J. (2006). What Ever Became of Solidarity? America Magazine, 16.01.2006.

Beyer, Gerald J. (2009). Freedom as a Challenge to an Ethic of Solidarity in a Neoliberal Capitalist World: Lessons from Post-1989 Poland. Journal of Catholic Social Thought 6(1), 133-167.

Bielasiak, Jack (2010). The paradox of Solidarity's legacy: contested values in Poland's transitional politics. Nationalities Papers 38(1), 41-58.

Bill, Stanley, Ben Stanley (2020). Whose Poland is it to be? PiS and the struggle between monism and pluralism. East European Politics 36(3), 378-394.

Bonowicz, Wojciech (2002). Słowa, których nie wolno zapomnieć [Words that cannot be forgotten]. In: Dariusz Gawin (ed.). Lekcja Sierpnia: Dziedzictwo „Solidarności” Po Dwudziestu Latach [The August Lesson: The Legacy of Solidarność Twenty Years Later]. Warszawa: Wydawnictwo IFiS PAN, 63-76.

Brzeziński, Michał, Michał Myck and Mateusz Najsztub (2020). Income Inequality in Transition. New results for Poland Combining Survey and Tax Return Data. Last accessed 11.04.2021 on https://freepolicybriefs.org/2020/01/13/income-inequality-in-transition-new-results-for-poland-combiningsurvey-and-tax-return-data/.

Brzeziński, Michał (2017). Is high inequality an issue in Poland? IBS Policy Paper. Last accessed 11.04.2021 on https://ibs.org.pl/app/uploads/2017/06/IBS_Policy_Paper_01_2017_en.pdf.

Bukowski, Paweł and Filip Novokmet (2019). Within a single generation, Poland has gone from one of the most egalitarian countries in Europe to one of the most unequal. LSE European Politics and Policy (EUROPP) blog, 02.12.2019. Last accessed 11.04.2021 on https://core.ac.uk/download/pdf/287596076.pdf.

Chrabota, Bogusław (2016). Ryzykowna ścieżka 500+ [A risky path of 500+]. Rzeczpospolita, 27.12.2016. Last accessed 11.04.2021 on https://www.rp.pl/Opinie/161229253-Boguslaw-Chrabota-Ryzykownasciezka-500.html.

Dudek, Antoni (2002). Rewolucja Robotnicza i Ruch Narodowowyzwoleńczy [Workers' Revolution and National-Independence Movement]. In: Dariusz, Gawin (ed.). Lekcja Sierpnia: Dziedzictwo „Solidarności" po Dwudziestu Latach [The August Lesson: The Legacy of Solidarność Twenty Years Later]. Warszawa: Wydawnictwo IFiS PAN, 143-158.

EAPN Polska (2020). Poverty Watch 2020 Poland. Monitoring poverty and social policy against poverty in Poland in 2019 and the first half of 2020. Last accessed 11.04.2021 on https://www.eapn.eu/wpcontent/uploads/2020/10/EAPN-Poverty-Watch-2020-Poland-4744.pdf.

Eurostat (2019). Minimum wages. Last accessed 11.04.2021 on https://ec.europa.eu/eurostat/statisticsexplained/index.php?title=File:Minimum wages, July 2019 (PPS per month).png.

Eurostat (2021). Gini coefficient of equivalised disposable income. EU-SILC survey. Last accessed 11.04.2021 on http://appsso.eurostat.ec.europa.eu/nui/show.do?dataset=ilc di12\&lang=en.

Frasyniuk, Władysław (2020). W sierpniu byliśmy razem [In August we were together]. Gazeta Wyborcza, 29.08.2020, 10-11.

Gawin, Dariusz (2002). "Solidarność” - Republikańska Rewolucja Polaków [Solidarność- A Republican Polish Revolution]. In: Dariusz, Dawin (Ed.). Lekcja Sierpnia: Dziedzictwo „Solidarności” Po Dwudziestu Latach [The August Lesson: The legacy of Solidarność Twenty Years Later]. Warszawa: Wydawnictwo IFiS PAN, 162-188.

Garton Ash, Timothy (1999). The Polish Revolution: Solidarity. London: Penguin Books. 
Gowin, Jarosław (2002). Kościół a Solidarność [Church and Solidarność]. In: Dariusz, Gawin (Ed.) Lekcja Sierpnia: Dziedzictwo „Solidarności” Po Dwudziestu Latach [The August Lesson: The Legacy of Solidarność Twenty Years Later]. Warszawa: Wydawnictwo IFiS PAN, 13-38.

Hechter, Michael (2001). Sociology of Solidarity. In: Neil J., Smelser and Paul B. Baltes (eds.). International Encyclopedia of the Social \& Behavioral Sciences. Amsterdam: Elsevier, 14588-14591.

Inglot, Tomasz (2020). The Triumph of Novelty over Experience? Social Policy Reponses to demographic Crises in Hungary and Poland since EU Enlargement, East European Politics and Societies and Cultures 34(4), 984-1004.

Kaczmarczyk, Paweł, Enrique Aldaz-Carroll and Paulina Hołda (2020). Migration and Socio-economic Transition: Lessons from the Polish Post-EU Accession Experience, East European Politics and Societies and Cultures 34(4), 910-936.

Krzemiński, Ireneusz (2010). Jaka Polska? Jacy Polacy? Śni mi sie Polska ... solidarna! [Which Poland? Which Poles? I dream of ... solidaristic Poland!]. In: Szomburg, Jan (ed.). Jak uszlachetnić nasze Polski? Kongres Obywatelski [How to make our Polands more noble? Citizens' Congress]. Gdańsk: Instytut Badań nad Gospodarką Rynkową, 49-53.

Krysiak, Paweł (2020). Bądźmy znów ludźmi [Let us be humans again]. Magazyn Gazety Wyborczej, 22.08.2020, 3-6.

Kubik, Jan (1994). The Power of Symbols Against the Symbols of Power. The Rise of Solidarity and the Fall of State Socialism in Poland. Pennsylvania: Pennsylvania State University Press.

Linz, Juan, J.; Stepan, Alfred (1996). Problems of Democratic Transition and Consolidation: Southern Europe, South America, and Post-Communist Europe. Baltimore and London: The John Hopkins University Press.

Linz, Juan J. (2000). Totalitarian and authoritarian regimes. Boulder, CO: Lynne Rienner Publishers.

Lubecki, Jacek and Lech Szczegóła (2007). "Polish exceptionalism": What explains low turnout in Polish post-communist elections? The Polish Review 52(1), 3-35.

Machcewicz, Anna (2020). Jak Było Naprawdę [How did it really go]. Gazeta Wyborcza, 29.08.2020, 56.

Maćków, Jerzy (2014). Widerstand («politische Opposition») und politische Gewalt im kommunistischen Totalitarismus. In: Krzysztof Łabędź, Małgorzata Świder (eds.). Opozycja antykomunistyczna w krajach bloku wschodniego w latach 1945-1989. Kraków: Uniwersytet Pedagogiczny, 21-34.

Maćków, Jerzy (2005). Totalitarismus und danach. Baden-Baden: Nomos.

Maćków, Jerzy (1999). Der Wandel des kommunistischen Totalitarismus und die postkommunistische Systemtransformation: Periodisierung, Problematik und Begriffe. Zeitschrift für Politikwissenschaft 4, 1347-1381.

Maćków, Jerzy (1992). Die Krise des Totalitarismus in Polen. Münster und Hamburg: LIT Verlag.

Maćków, Jerzy (1989). Polen im Umbruch: Die Wahlen 1989. Politische Hintergründe, Verlauf, Analyse. Zeitschrift für Parlamentsfragen 4, 561-580.

Marody, Mirosława (2011). Od społeczeństwa drugiego obiegu do społeczeństwa obywatelskiego [From second society to civil society]. Studia Socjologiczne 1(200), 483-500.

Marody, Mira (1990). Perception of Politics in Polish Society. Social Research 57(2), 257-274. 
Mazur, Krzysztof (2018). Mit 4: "Solidarność" to tylko Wałęsa [Myth 4: Solidarność was only about Wałęsa]. Last accessed 05.03.2021 on https://klubjagiellonski.pl/2018/08/16/mit-4-Solidarność-totylko-walesa-video/

Nowak, Stefan (1979). System wartości społeczeństwa polskiego [The value system of Polish society]. Studia Socjologiczne 4(75), 155-173.

Offe, Claus (1991). Capitalism by Democratic Design? Democratic Theory Facing the Triple Transition in East Central Europe. Social Research 58(4), 865-92.

Osa, Maryjane (2003). Solidarity and Contention. Networks of Polish Opposition. Minneapolis and London: University of Minnesota Press.

Ost, David (1990). Solidarity and the Politics of Antipolitics: Opposition and Reform in Poland Since 1968. Philadelphia: Temple University Press.

Prawo i Sprawiedliwość (2019). Program Prawa i Sprawiedliwości: Polski Model Dobrobytu [The program of Law and Justice. Polish model of welfare]. Last accessed 02.02.2021 on http://pis.org.pl/files/Program_PIS 2019.pdf.

Sadura, Przemysław and Sławomir Sierakowski (2019). Polityczny cynizm Polaków [Political cynic of Poles]. Warszawa: Stowarzyszenie im. Stanisława Brzozowskiego, Fundacja Pole Dialogu i Autorzy. Last accessed 02.02.2021 on https://poledialogu.org.pl/wp-content/uploads/2019/09/Politycznycynizm-Polakow_Raport.pdf.

Sartori, Giovanni (1987). The Theory of Democracy Revisited. Chatham: Chatham House Publishers.

Smolar, Aleksander (2019). Transfer godności, strachu, równości i wspólnotowości, czyli jak PiS wygrał. I co $z$ tym zrobić [The transfer of dignity, equality and community, or how PiS won and what to do with it]. Last accessed 02.02.2021 on https://oko.press/smolar-transfer-godnosci-strachu-rownoscii-wspolnotowosci-czyli-jak-pis-wygral/.

Solska, Magdalena (2009). Systemwechsel und Unabhängigkeit: Polen und Litauen 1988-1991. In: Jerzy Maćków (ed.). Autoritarismus in Mittel- und Osteuropa. Wiesbaden: VS Verlag für Sozialwissenschaften, 182-197.

Staniszkis, Jadwiga (1984). Poland's Self-Limiting Revolution. Princeton: Princeton University Press.

Stawrowski, Zbigniew (2002). Doświadczenie Solidarności Jako Wspólnoty Etycznej [The Experience of Solidarity as Ethical Community]. In: Dariusz Gawin (Ed.). Lekcja Sierpnia: Dziedzictwo „Solidarności" Po Dwudziestu Latach [The August Lesson: The Legacy of Solidarność Twenty Years Later]. Warszawa: Wydawnictwo IFiS PAN, 103-122.

Stawrowski, Zbigniew (2000). O zapomnianej Solidarności [On forgotten Solidarność]. Znak 543, 6067.

Szacki, Jerzy (1996). Liberalism After Communism. Budapest: Central European University Press.

Szczerbiak, Alex (2019). Why is Poland's Law and Justice party still so popular? Last accessed 30.11.2021 on https://blogs.lse.ac.uk/europpblog/2019/10/01/why-is-polands-law-and-justice-party-still-sopopular/.

Taylor, Charles (2002). Kilka refleksji na temat Solidarności [Some reflections on Solidarność]. Znak 543, 22-34. 
Tischner, Józef (2005). The Ethics of Solidarity. Selected by Dobrostaw Kot. Last accessed 05.03.2021 on http://www.tischner.org.pl/Content/Images/tischner 3 ethics.pdf

Touraine, Alain, Dubet, Fracois, Wieviorka, Michel, Strzelecki, Jan (1983). Solidarity: Poland 1980-81. Cambridge: Cambridge University Press.

Trudnowski, Piotr (2017). Program 500+ to dochód gwarantowany. Tyle, że na dzieci [DEBATA cz. 1] [The $500+$ program is a guaranteed income, but on children. Debate, part 1]. Last accessed 11.04.2021 on https://klubjagiellonski.pl/2017/07/15/program-500-dochod-gwarantowany-tyle-zena-dzieci-debata-cz-1-marczuk-gromada-morawski-kedzierski/

World Bank (2018). Fertility rate, total (births per woman) Poland. Last accessed 11.04.2021 on https://data.worldbank.org/indicator/SP.DYN.TFRT.IN?locations=PL

Wójcik, Piotr (2019). Nierówności w Polsce największe w Europie czy też nie? [Inequalities in Poland are the greatest in Europe or are not?]. Krytyka Polityczna, 27.08.2019. Last accessed 11.04.2021 on https://krytykapolityczna.pl/kraj/nierownosci-w-polsce-badania-wskazniki-interpretacje/

Wujec, Henryk (2020). Interview by Magdalena Solska on 12.2.2020, Warsaw. $<<<<<<<~$ 